\title{
Cytoplasmic Protein
}

National Cancer Institute

\section{Source}

National Cancer Institute. Cytoplasmic Protein. NCI Thesaurus. Code C20033.

Protein within the interior of the cell; excludes membrane, mitochondrial, and nuclear proteins. 